\title{
The German public company limited partnership (Kommanditgesellschaft auf Aktien - KGaA)
}

\author{
by Frank Wooldridge
}

The above type of entity is defined in Article 287(1) AktG as one which has a separate legal personality, and which no less than one partner has unlimited liability with respect to its creditors (personally liable or general partner), whilst the other shareholders who are not personally liable for the company's obligations (Kommanditaktionäre) participate in the share capital. A similar private company limited partnership (GmbH \& CoKG) also exists in Germany and is frequently used as an alternative to the KGaA. Both types of entity also exist in Austria. The KGaA is frequently used by business entities, particularly by medium sized ones.

It should be evident from its name that a $\mathrm{KGaA}$ is a hybrid entity which has some of the characteristics of a limited partnership (Kommanditgesellschaft) and some of those of a public company (Aktiengesellschaft) A Kommanditgesellschaft is an entity in which at least one of the members has unlimited liability, whilst the liability of the others is limited to the amounts unpaid on their shares. The former members are called Komplementäre (general partners) whilst the others are called Kommanditisten (limited partners). The shares in such an entity may be in bearer or registered form. Such an entity is subject to employee codetermination in accordance with the Codetermination Act of 1976 (Mitbestimmungsgesetz) and the One Third Participation Act (Drittelbeteiligunmgsgesetz) of 2001

\section{LEGAL RULES APPLICABLE TO THE KGaA}

The most important rules are set out in Articles 278(2) and (3) of the Aktiengesetz. Article 278(2) AktG which provides that the legal relations of the general (or unlimited) partners between themselves and with respect to the body of limited shareholders (Kommanditaktionäre) and to third persons, in particular the authority of the general partners to manage the business and to represent its company, shall be governed by the provisions of the Commercial Code regarding limited partnerships. Article 278(2) AktG stipulates that the provisions of Book 1 of the German Companies Act, which are Articles
1-277 thereof, shall apply by way of analogy to the partnership limited by shares, unless the following provisions or the absence of a management board required otherwise.

\section{THE NAME OF A KGaA}

The name of a KGaA is required by Article 279(1) AktG to contain the designation Kommanditgesellschaft auf Aktien, or a generally comprehensible abbreviation of that designation (for example $\mathrm{KGaA}$ ). Article 279(2) AktG provides that if none of the shareholders is a natural person who is personally liable, the name shall, even if it is continued pursuant to Article 22 of the Commerical Code or some other statutory provision, contain a designation including the limitation of liability.

\section{THE POSITION OF A GENERAL PARTNER}

A general partner (Komplementär) is personally liable for the debts and obligations of the company, and is thus required to contribute without limit to the losses of $\mathrm{KGaA}$. The Komplementär is in a different position from a limited shareholder (Kommanditaktionäre) who is not personally liable to make a contribution to the company's creditors consisting of the amount unpaid on his shares. A general partner is not required to contribute to the capital of the company, although in practice he often does so. A general partner may be a natural person, and it appears that such a partner may also be a legal person, at least where another general partner is a natural person.

It is possible for a $\mathrm{KGaA}$ to be a one-person entity, the Komplementär and the Kommanditaktionäre being the same person.

\section{THE SUPERVISORY BOARD}

A partnership limited by shares must have a supervisory board, which according to Article 287(2) AktG, is required to carry out the resolutions of the limited shareholders, 
unless the articles otherwise provide. Article 287(2) AktG stipulates that the supervisory board shall represent the limited shareholders except where the shareholders' meeting has elected special representatives, in the event of litigation by the limited shareholders as a body against the general partners, or in that of litigation by the general partners against the limited shareholders as a body.

\section{Dr Frank Wooldridge}

